Nuntius Antiquus, Belo Horizonte, v. 12, n. 2, p. 27-48, 2016

\title{
A Polifonia do Platonismo: Alcínoo e Máximo de Tiro
}

\section{The Poliphony of Platonism: Alcinous and Maximus of Tyre}

\author{
Bernardo Lins Brandão \\ Universidade Federal do Paraná \\ Curitiba, Paraná / Brasil \\ bgslbrandao@gmail.com
}

Resumo: Se, nos dias de hoje, na tradição analítica, o principal atributo da filosofia é o argumento lógico, na Antiguidade, ela podia abarcar a retórica e envolver um modo distinto de vida. Neste artigo, analiso dois conceitos de filosofia, apresentados por dois filosófos medioplatônicos: Alcínoo, autor do Didascálicos, e Máximo de Tiro, que escreveu as Dialéxeis. Como integrantes de um mesmo movimento filosófico, a visão deles é, em certos aspectos, similar: ambos consideram a filosofia como uma forma de conhecimento das coisas humanas e divinas que possui consequências éticas. Mas, se para Alcínoo o modo de vida filosófico é o theorentikós bíos, o ideal de Máximo é o do orador filosófico, o que é possível para ele por causa de sua noção da polifonia da filosofia.

Palavras-chave: medioplatonismo; filosofia como modo de vida; retórica antiga.

Abstract: If nowadays, in the analitycal tradition, philosophy's key feature is logic argument, in Antiquity, philosophy could embrace rhetoric and a distinct way of life. In this paper, I analyse two conceptions of philosophy, presented by two middle platonic philosophers: Alcinous, author of the Didascalics, and Maximus of Tyre, who wrote the Dialéxeis. As a part of the same philosophical movement, their views are, in some ways, similar: both authors consider philosophy as a form of knowledge of things human and divine that has ethic consequences. But, if Alcinous' philosophical way of life is the theoretikós bios, 
Maximus' ideal is the philosophical orator, which is possible for him because of his notion of the polyphony of philosophy.

Keywords: middle Platonism; philosophy as a way of life; ancient rhetoric.

Recebido em 10 de outubro de 2016. Aprovado em 1 de dezembro de 2016.

\section{0 que é filosofia}

O que é filosofia? Nigel Warburton, em seu livro Elementos de Filosofia (1998, p. 10), escreve: “A filosofia é uma atividade: é uma forma de pensar acerca de certas questões. Sua característica mais marcante é o uso de argumentos lógicos. A atividade dos filósofos é, tipicamente, argumentativa: ou inventam argumentos ou criticam os argumentos de outras pessoas ou fazem as duas coisas. Os filósofos também analisam e clarificam conceitos. A palavra filosofia é muitas vezes usada num sentido muito mais lato que este, para se referir a uma perspectiva geral da vida ou alguma forma de misticismo". Warburton fala em uma acepção mais geral e vaga, que é como uma certa visão de mundo, e um sentido mais específico, no qual o elemento marcante é a argumentação lógica, que capta bem o espírito da filosofia contemporânea em língua inglesa. Uma descrição como essa, no entanto, não capta as nuances e o campo de possibilidades que a atividade filosófica possuía na Antiguidade.

A esse respeito, é bastante instrutivo o artigo de G. Stanton (1993), "Sophists and Philosophers: some problems of demarcation". Ao examinar como autores dos séculos I e II d.C. pensavam sobre si mesmos, Stanton constatou que a visão que tinham de si era, em alguns casos, um tanto diversa da que hoje temos deles. ${ }^{1}$ Nas palavras de Lauwers (2013, p. 331), ${ }^{2}$ ao comentar o artigo, "com efeito, os estudiosos

\footnotetext{
${ }^{1}$ Stanton estuda o uso dos termos sophistés e philósophos em Plutarco, Díon Crisóstomo, Élio Aristides, Epicteto e Marco Aurélio. Mas o caso de Díon é o mais importante para nossos propósitos: estudado nos dias de hoje como um sofista, considerava-se um filósofo e assim era visto por Luciano (Peregrino, XVIII) e Fócio (Biblioteca, CCIX). ${ }^{2}$ A tradução é minha.
} 
modernos decidiram por si mesmos que autores eles consideram filósofos e que autores consideram sofistas". Como uma profecia que cumpre a si mesma, a partir de alguns exemplos de filósofos, cria-se uma certa noção de filosofia que, por sua vez, será usada para justificar os exemplos escolhidos, em uma espécie de petição de princípio. Trata-se de "uma abordagem prescritiva, e não descritiva, da situação histórica, e não faz justiça à realidade histórica tal como percebida pelos autores do período imperial" (LAUWERS, 2013, p. 332).

Em seu livro de 2015, Lauwers avança a investigação de Stanton, mostrando que autores como Díon Crisóstomo, Favorino, Máximo de Tiro e Apuleio, vistos nos dias de hoje como oradores e sofistas, consideravam-se e eram considerados pelos antigos como filósofos. Para tornar mais claro o contexto, ele propõe a hipótese da existência de dois sistemas semânticos a partir dos quais os termos sophistés e philósophos eram usados no período imperial: no primeiro sistema, o termo sophistés era usado de maneira pejorativa, como um contraponto à noção de philósophos. É o uso que aparece em autores como Epicteto, Marco Aurélio e no próprio Máximo de Tiro. No segundo sistema, os termos não são opostos, mas complementares. É o caso de Filóstrato, para quem "devemos considerar a antiga arte sofística como retórica filosófica" (Vidas, CDLXXX).

Mas, mesmo para os autores que, a partir do primeiro sistema, criticavam a sofística, não havia necessariamente oposição entre a filosofia e a retórica. Apuleio, por exemplo, enfatizando a eloquência de Platão, considerava a retórica útil para a atividade filosófica (Florida VII, 10). Em outros casos, no entanto, essa combinação nem sempre era bem vista: segundo Filóstrato (Vida dos Sofistas, CDXC), Favorino, ao buscar imunidade diante da convocação para ser sacerdote em sua terra natal, quase não a obteve porque o imperador Adriano, que sabia de sua eloquência, não o considerava um filósofo. Isso indica que o termo philósophos não era entendido de maneira unívoca na Antiguidade e que poderia comportar uma maior ou menor tolerância para com a habilidade retórica.

Acredito que os estudos de Pierre Hadot podem-nos ser úteis aqui: para ele (HADOT, 1999, p. 265), a filosofia na Antiguidade era "um modo de existir no mundo que devia ser praticado a cada instante, cujo objetivo era transformar a totalidade da vida individual". Mas, se a compreendemos dessa maneira, como um modo de vida segundo a 
razão, ${ }^{3}$ então não apenas o texto argumentativo do tratado ou do diálogo, mas também o discurso do orador que incita o ouvinte a adotar uma determinada conduta torna-se uma possibilidade da filosofia. Nessa perspectiva, autores como Máximo de Tiro e Díon Crisóstomo não parecem tão deslocados assim.

O trabalho de Hadot, no entanto, por ser uma síntese, é inevitavelmente panorâmico e requer o complemento de pesquisas pontuais que apontem para a especificidade da noção de filosofia nos vários autores da Antiguidade. É por isso que talvez seja mais adequado falar, com John Cooper (2012), não em um modo de vida filosófico, mas em modos de vida. ${ }^{4}$ É o que pretendo fazer aqui com dois autores do medioplatonismo, Alcínoo e Máximo de Tiro. Acredito que estudá-los em um mesmo texto pode evidenciar a riqueza de matizes que a atividade filosófica podia adquirir, mesmo em uma mesma tendência, como o platonismo do período imperial: enquanto Máximo parece ter sido um orador itinerante cujos textos que chegaram até nós são transcrições dos discursos que proferiu em sua primeira estadia em Roma, tudo o que temos de Alcínoo é um manual escolar que apresenta uma síntese das doutrinas de Platão tal como ele as interpreta a partir dos diálogos.

\section{Alcínoo}

Não se sabe ao certo quem foi Alcínoo. Tudo o que temos dele é seu Didascálicos, um manual de filosofia platônica. Alguns estudiosos tentaram identificá-lo ao filósofo Albino, ligado à escola de Gaio, mas, desde Whittaker (1974), muitos não acreditam haver argumentos sólidos para tal. De qualquer modo, sua interpretação de Platão, suas teses e terminologia apontam que tenha escrito o tratado entre os séculos I e II d.C. O texto não deixa de ser um resumo escolar, mas é a única síntese, ao lado do Sobre as doutrinas de Platão de Apuleio, do platonismo do período imperial anterior a Plotino e, por isso, uma das mais importantes

\footnotetext{
${ }^{3}$ Por entender que essa é a perspectiva de Hadot, discordo da crítica de Sellars (2009, p. 116), quando ele afirma que Hadot se esqueceu da proeminência do lógos na filosofia, não a diferenciando de outras formas de vida do mundo antigo. Para Hadot (1999, p. 251), existe uma relação mútua, na qual o lógos condiciona a vida e a vida, por sua vez, condiciona o lógos.

${ }^{4}$ Daí o título do seu livro a esse respeito (2012), Pursuits of wisdom: six ways of life in ancient philosophy, from Socrates to Plotinus.
} 
fontes para a sua interpretação. Já no início, Alcínoo apresenta sua definição da filosofia:

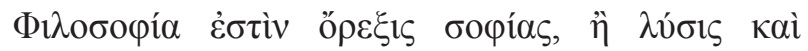

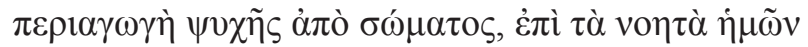

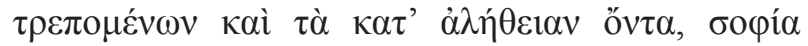

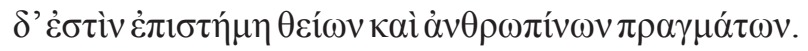

A filosofia é o desejo pela sabedoria ou a libertação e a conversão da alma, quando nos afastamos do corpo e nos voltamos para os inteligíveis, os entes verdadeiros; a sabedoria é a ciência das coisas divinas e humanas. $^{5}$

A definição parte da etimologia do termo, mas, em vez de philía, Alcínoo fala em órexis, termo que pode ser traduzido como tendência ou propensão, mas que parece indicar aqui, segundo Dillon (2002, p. 51), o desejo racional. Essa definição não é exclusiva de Alcínoo, mas parece ter sido corrente no medioplatonismo: é atestada em Nicômaco de Gerasa (I, 2, 5) e em uma versão ligeiramente modificada (a órexis pela sabedoria divina), no resumo da doutrina platônica em Diógenes Laércio, Vidas III, 63. A sabedoria, por sua vez, é definida como um tipo de epistéme, ou seja, um conhecimento certo a partir das causas, mais precisamente, a ciência das coisas divinas e humanas, o que parece indicar o conhecimento da totalidade e de seus princípios. Como nota Dillon (2002, p. 52), também esta parecia ser uma definição corrente no período, de provável inspiração estoica, mas adotada por autores variados como Cícero (Tusculanas IV, 26, 57) e Apuleio (De Platone et eius dogmate II, 6, 228).

A segunda definição é baseada no Fédon 67d, no qual se fala em lúsis e khorismós (libertação e separação) da alma com relação ao corpo. Mas Alcínoo fala não em separação, mas em periagogée, uma reviravolta da alma (que traduzo por conversão) que desvia sua atenção dos assuntos ligados ao mundo corpóreo e a volta para o inteligível. A lúsis e a periagogé podem ser entendidas de duas maneiras: (1) em uma chave epistemológica, como um esforço da alma de não mais buscar

\footnotetext{
${ }^{5}$ Alcínoo, Didascálicos I, 1. A tradução de todas as passagens citadas em grego é de minha autoria.
} 
conhecer exclusivamente por meio da aísthesis e da phantasía que dela deriva, mas por meio da nóesis, da intelecção, dos inteligíveis; (2) em uma perspectiva ética, envolvendo também as paixões, os hábitos e a conduta, ou seja, como um modo de vida que põe como um valor superior o inteligível e não o corpóreo. A leitura mais simples é a que adota a chave epistemológica, mas a sequência do texto dá a entender que a perspectiva ética também é considerada por Alcínoo:

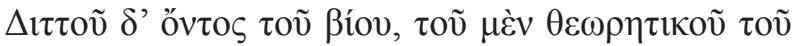

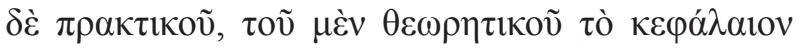

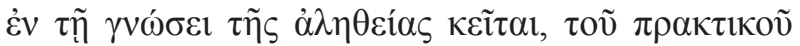

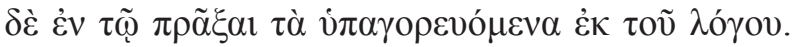

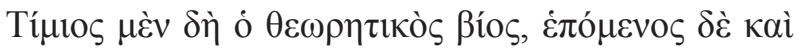

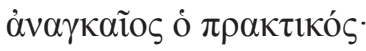

A vida é dupla: teorética e prática. O essencial da vida teorética está no conhecimento da verdade, enquanto o da vida prática, no fazer o que é aconselhado pela razão. O mais valioso é a vida teorética, seguindo-se e necessária, a vida prática. ${ }^{6}$

Como observa Dillon (2002, p. 53), a distinção entre vida teorética e prática, em sua forma explícita, se encontra em Aristóteles (por exemplo, na Ética X, 7), mas, segundo Clemente de Alexandria (Stromata II, 5), remonta a Xenócrates. Alcínoo não fala aqui em duas vidas, entretanto, mas em uma vida dupla (SEDLEY, 2012, p. 179), que possui um aspecto teorético e outro prático. $\mathrm{O}$ texto, desse modo, parece dizer respeito à vida filosófica, que envolve a busca pelo conhecimento, mas que também comporta um aspecto ético, no qual a ação segue o que é aconselhado pelo lógos.

O mais valioso, contudo, Alcínoo afirma, é a theoría. O termo também não está isento de dificuldades, parecendo adquirir duas acepções no Didascálicos: (1) em textos como o citado acima (II, 1), podemos ler o theoretikós como uma referência à theoría enquanto investigação e estudo. (2) No entanto, em II, 2, o termo é definido como uma enérgeia específica, a nóesis dos inteligíveis:

${ }^{6}$ Alcínoo, Didascálicos II, 1. 


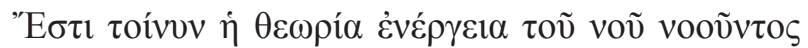

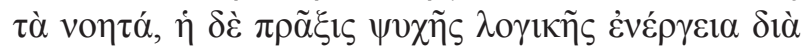

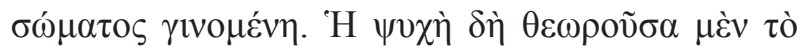

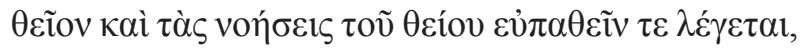

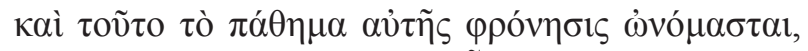

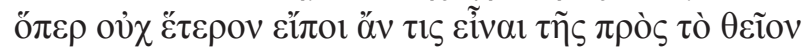
ó $\cot \sigma \varepsilon \omega s$.

A contemplação é a atividade do intelecto que faz a intelecção dos inteligíveis. A ação é a atividade da alma racional que se faz através do corpo. Diz-se que a alma que contempla o divino e as intelecções do divino se regozija; esse seu estado é chamado de prudência, que eu diria não ser outra coisa que a semelhança com o divino. ${ }^{7}$

A theoría é uma enérgeia, o que, para Dillon (2002, p. 55), deve ser entendido aqui no sentido aristotélico de atualização de uma potência: é a atualização do noús, a potência da alma responsável pelo "pensamento intuitivo ou não proposicional, em oposição à cognição discursiva". ${ }^{8}$ Em outras palavras, a theoría é a intelecção. Por sua vez, a práxis é, por um lado, também uma enérgeia da alma racional, mas, por outro, se faz através do corpo: a ação enquanto segue os ditames da theoría. O modo de vida filosófico comporta, assim, duas dimensões, ligadas em uma relação de dependência: o mais importante é a theoría, mas a práxis que dela deriva, ainda que inferior, é também necessária (Alcínoo usa em II, 1 o termo anankaîos).

O texto se segue de uma forma mais obscura, quando Alcínoo fala sobre o estado ideal desse modo de vida: a alma que realiza a intelecção do divino e as intelecções do divino se regozija. Para Dillon, o verbo eupatheîn é uma referência ao Fedro 247 d, onde se diz que a alma que contempla a verdade se alimenta e se regozija. O termo

\footnotetext{
${ }^{7}$ Alcínoo, Didascálicos II, 2.

${ }^{8}$ Penso que Dillon está certo em falar em pensamento não proposicional, mas acho inadequada a ideia de uma oposição ao pensamento discursivo, já que me parece que a nóesis é a captação dos aspectos universais e necessários (ou seja, inteligíveis) da realidade alcançados a partir do raciocínio discursivo (a diánoia, para usar a terminologia platônica adotada por Alcínoo) que os busca.
} 
indica um estado de bem estar, um bom páthos, mas, para Dillon (2002, p. 55), deve ser tomado a partir de suas conotações estoicas, indicando o equivalente racional das paixões. Alcínoo também afirma que esse estado é a phrónesis, termo que, para Aristóteles, sinaliza a sabedoria prática, mas que, em Platão, é usado para denotar a sabedoria em geral. ${ }^{9}$

Alcínoo afirma em IX, 1 que são três os princípios: a matéria, as formas e o deus. Tendo isso em vista, acredito que, quando ele fala em divino (termo que poderia ser, a princípio, empregado para falar também das formas inteligíveis), ele se refere ao deus. É que, logo em seguida, ele fala das intelecções do divino, sendo que, seguindo uma tendência do medioplatonismo, ele considera as formas inteligíveis como pensamentos do deus, que é concebido, assim, como um intelecto. Alcínoo parece dar a entender, portanto, que quando a alma alcança a phrónesis, ela tem a theoría não apenas das formas, mas também do princípio delas, o deus.

O ideal da contemplação do deus era comum entre os filósofos medioplatônicos. Justino, no séc. II d.C., em seu Diálogo contra Trifão, narra sua experiência como estudante da filosofia platônica em termos semelhantes, falando da nóesis dos inteligíveis e da esperança da contemplação do deus, ${ }^{10}$ que, segundo ele, seria o télos da filosofia platônica, alcançada subitamente, por meio do olho do intelecto. ${ }^{11}$

\footnotetext{
${ }^{9}$ Para Dillon, trata-se de uma reminiscência do Fédon 79d, no qual se fala de um estado da alma que é chamado de phrónesis.

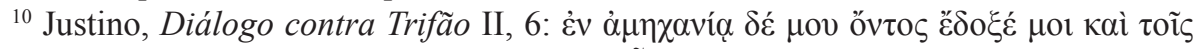

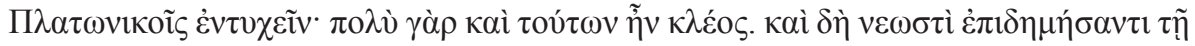

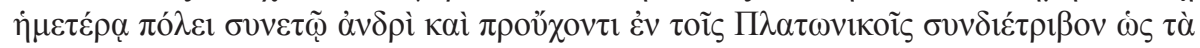

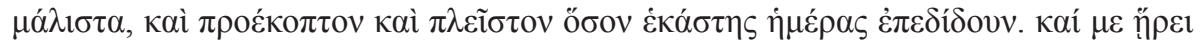

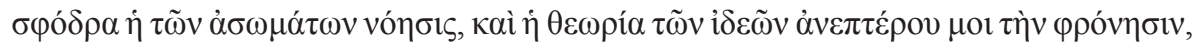

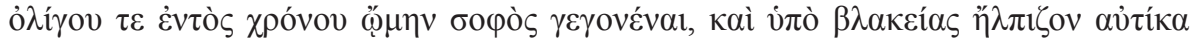

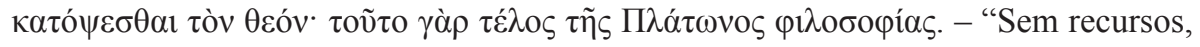
pareceu-me que devia me encontrar com os platônicos, pois também eles tinham muita fama. E, recentemente, chegara à nossa cidade um homem sagaz, proeminente entre os platônicos; passava muitíssimo tempo com ele e me adiantava cada vez mais enquanto me dedicava a cada dia. Eu me exaltava principalmente com a intelecção dos incorpóreos e a contemplação das formas dava asas à minha inteligência. Em pouco tempo pensava que me tornaria sábio e, pela estupidez, esperava subitamente ver o deus. Pois esta é a meta da filosofia de Platão".

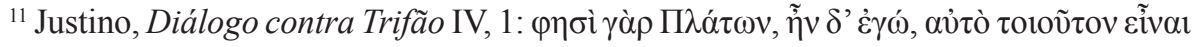

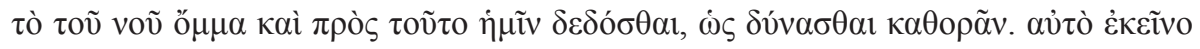


Penso, no entanto, que um dos maiores problemas que temos para uma compreensão adequada do medioplatonismo é justamente entender o que seria isso. Pois, se para Justino, o princípio supremo não é dizível e está para além de toda essência (Diálogo contra Trifão II, 6), também para Alcínoo ele é inefável:

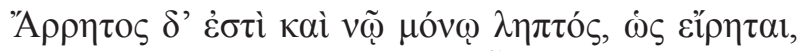

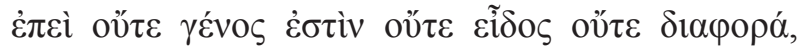

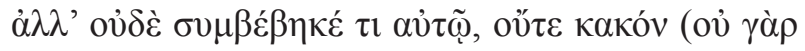

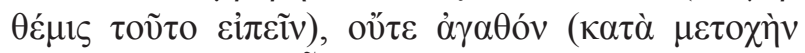

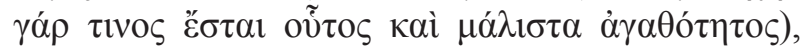

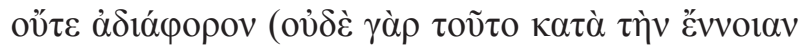

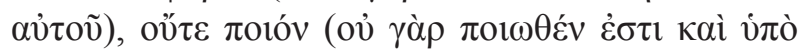

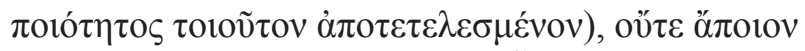

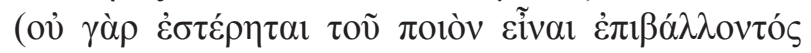

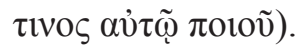

Ele é inefável e captável apenas pelo intelecto, como se disse, já que não é nem um gênero, nem espécie, nem diferença, nem possui algum atributo, nem é mau (pois isso não é lícito dizer), nem bom (pois ele seria assim por participação em algo, especialmente na bondade), nem indiferente (pois nem isso está de acordo com a noção que temos dele), nem tem alguma qualidade (pois não é qualificado, nem se torna perfeito através de alguma qualidade), nem sem

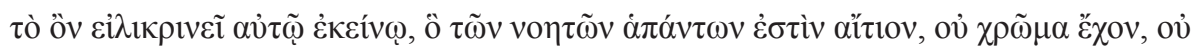

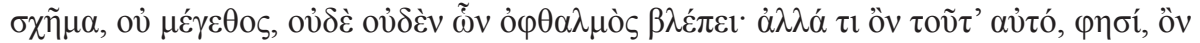

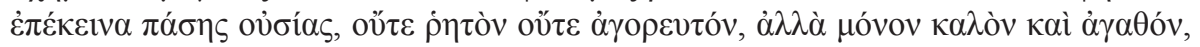

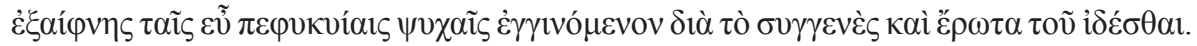
- "Platão, pois, eu disse, afirma que assim é o olho do intelecto, e que ele nos foi dado para ver, assim como é possível, com ele mesmo, sem mistura aquele próprio ser que é causa de tudo o que é inteligível, sem ter cor, sem forma, sem tamanho, sem nada daquilo que o olho vê, mas que é o próprio ser. Ele diz que é ser sobre toda substância, nem dizível, nem proclamável, o único belo e bom que aparece imediatamente nas almas bem constituídas, pelo parentesco e desejo de ver". 
qualidade (pois não é privado de alguma qualidade que deveria pertencer a ele). ${ }^{12}$

Vemos, tanto em Justino quanto em Alcínoo, um primeiro esboço do que se constituirá em Plotino como um verdadeiro discurso apofático a respeito do primeiro princípio e que, com o pseudo-Dionísio Areopagita, se tornará teologia negativa. No entanto, se para Plotino o Um é conhecido por meio de uma presença superior à epistéme (VI, 9, 4), ou seja, por uma experiência unitiva que transcende a capacidade do noús da alma, em Alcínoo o deus é conhecido pelo noús, ainda que não da mesma maneira que as formas inteligíveis, já que não possui gênero, espécie, diferença ou outra forma de delimitação.

Alcínoo fala de três maneiras pelas quais podemos ter a nóesis do divino: em primeiro lugar, por meio da apháiresis, pela qual, por meio da supressão de atributos, podemos entender algo da divindade, tal como podemos entender o que é um ponto concebendo uma superfície e em seguida uma linha, para finalmente chegar ao ponto $(X, 5)$. Essa seria a função do discurso apofático que, no entanto, não é suficiente para que tenhamos uma ideia do que o deus de fato seja, mas apenas do que ele não é. Em segundo lugar, segundo a analogia (kat'analogían): tal como o sol está para a visão, tornando-a possível, o deus, que é o primeiro intelecto, está para o nosso intelecto, sendo a causa de nossa intelecção (Didascálicos, X, 4). Esse segundo procedimento já nos traz algum conhecimento positivo, mas é feito, no entanto, por meio de uma semelhança. Existe também um terceiro procedimento, que parece nos proporcionar uma theoría mais plena. Trata-se de um caminho de ascensão inspirado na parte final do discurso de Sócrates no Banquete: deve-se contemplar a beleza dos corpos, em seguida a beleza da alma, a beleza das leis e costumes e, finalmente, o grande oceano do belo, a partir do qual torna-se possível a intelecção do deus. Alcínoo, contudo, não dá maiores detalhes a esse respeito. Essa ascensão, que já é de difícil interpretação em Platão, é ainda mais complicada aqui, já que não se refere ao belo inteligível, mas à intelecção do deus que é o princípio supremo da realidade: estaríamos aqui diante de uma mera interpretação da passagem do diálogo platônico, de uma promessa a ser cumprida em um momento indefinido, talvez quando a alma já não mais se encontrasse

\footnotetext{
${ }^{12}$ Alcínoo, Didascálicos X, 4.
} 
ligada ao corpo, após a morte, ou de alguma prática contemplativa, racional ou suprarracional, de algum modo próxima à que Plotino descreve nas Enéadas?

De qualquer maneira, essa contemplação é considerada por Alcínoo como sendo uma semelhança com o divino, outra expressãochave para definirmos o modo de vida filosófico apresentado no Didascálicos. A expressão é baseada no Teeteto 176 a-b, no qual Sócrates afirma que, como os males rondam por necessidade o nosso mundo corpóreo, é necessário fugir dos males daqui, o que deve ser feito através da semelhança com o deus por meio da virtude. É uma passagem central para a ética medioplatônica: a quase totalidade dos autores do período dos quais conhecemos as doutrinas éticas afirmam que é algo desse tipo o télos da vida humana. Mas em II, 2, Alcínoo se afasta do texto platônico em dois detalhes: (1) ele fala da semelhança com o divino, não com o deus, deixando a interpretação um pouco mais aberta; (2) não fala em virtude, mas em uma eupátheia.

Poderíamos ler, assim, a noção de semelhança com o divino em uma chave epistemológica, mas o texto de XVIII, 4 nos faz perceber que, novamente, o elemento ético não pode ser desconsiderado:

'Е

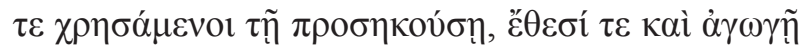

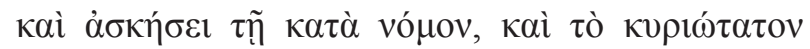

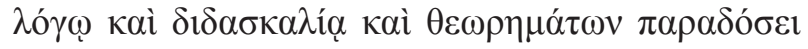

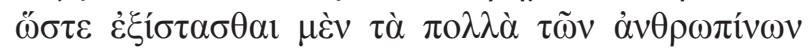

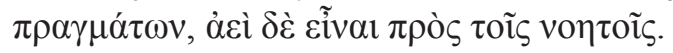

Alcançamos o tornarmo-nos semelhantes ao deus pela natureza e usando o que se segue: de acordo com o costume, os hábitos, um modo de vida e o exercício, bem como o mais importante: o discurso, o ensinamento e a transmissão das coisas contempladas, de modo a deslocarmo-nos de grande parte dos assuntos humanos e estarmos sempre junto dos inteligíveis. ${ }^{13}$

${ }^{13}$ Alcínoo, Didascálicos XVIII, 4. 
Para nos tornarmos semelhantes ao divino, que em II, 2 Alcínoo tornava equivalente à phrónesis e à theoría do deus e das formas inteligíveis por meio de atividades teoréticas e práticas, o mais importante (kuriótaton) são as atividades teoréticas: o lógos, o ensinamento e a transmissão do que foi contemplado (o que entendo como a instrução na qual um filósofo mais experiente busca transmitir o que contemplou ao seu discípulo). No entanto, existe também um lugar para a práxis: os hábitos, a agogé (termo que pode ser traduzido por conduta ou mesmo modo de vida) e a áskesis, o exercício, termo cuja acepção aqui não me parece tão distante daquilo que Hadot chama de exercícios espirituais. ${ }^{14}$

O objetivo de todas essas atividades é deslocarmos nossa atenção dos assuntos humanos e voltá-la para o inteligível. Como o deus de Alcínoo é um intelecto cujos pensamentos são as próprias formas inteligíveis, podemos então compreender o sentido último do modo de vida filosófico proposto por ele: uma semelhança com o divino que é, em última análise, a imitação da atividade do deus, a theoría. Se essa vida envolve mais que a intelecção, mas também diz respeito a hábitos, exercícios e um modo de vida, é que a vida humana, ligada a um corpo, não é uma atividade pura do espírito, mas envolve por necessidade a práxis, que deriva, por um lado, da theoría, mas que, por outro, a torna possível.

\section{Máximo de Tiro}

Segundo Eusébio de Cesareia em sua Crônica, Máximo tornou-se proeminente ao redor da 232a. Olimpíada, o que corresponde ao período de 149-153 d.C. Mas, para Lauwers (2015, p. 1), os textos de Eusébio não são historicamente dignos de confiança. É melhor, ele tomarmos como base a Suda, que se baseia no Onomatológos de Hesíquio, e situa Máximo em um período posterior, no reino de Cômodo (180-192 d.C.). Sua obra, as Dialéxeis, consiste num conjunto de 41 pequenos textos que, segundo a Suda, são a transcrição de discursos proferidos durante sua primeira estada em Roma. No primeiro discurso, Máximo parece dar a

\footnotetext{
${ }^{14}$ A expressão foi consagrada por São Inácio de Loyola, mas os exercícios inacianos têm como origem remota os exercícios filosóficos da tradição greco-romana. Além

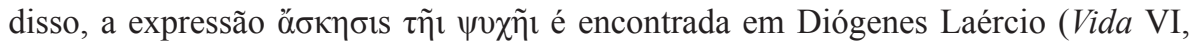
70), Musônio Rufo (fr. 6) e Clemente de Alexandria (Stromata VII, 16).
} 
entender que adquiriu certa fama em performances anteriores, fazendo parecer que era uma espécie de orador filosófico itinerante, a viajar pelas grandes cidades do Mediterrâneo proferindo seus discursos, que eram apreciados por sua eloquência, mas também por seu conteúdo moral e filosófico. Os temas são variados, ligados em geral à cultura filosófica e eram dirigidos, com grande probabilidade, a jovens que desejavam se iniciar no estudo da filosofia.

No entanto, o principal manuscrito de seus textos, o Parisinus Graecus 1962, apresenta-o não apenas como um filósofo, mas como um filósofo platônico. De fato, a maior parte das teses que apresenta possuem matizes medioplatônicos. Contudo, a classificação é causa de debate entre os estudiosos. Para Koniaris (1983), que nota que, em nenhum momento, Máximo se declara um platônico, ele falaria, em cada um dos diálogos, como uma persona de uma escola filosófica diferente. Michael Trapp, por sua vez, na introdução aos discursos de Máximo (1997, p. xxv), insiste no seu platonismo, afirmando que, apesar de certas tendências estoicas e cínicas em alguns discursos, a maior parte das teses de Máximo é de origem medioplatônica. Já Lauwers (2015, p. 211) acredita que ele não se define a partir de nenhuma escola, por causa de sua tese da harmonia entre os filósofos que, pensando a partir do ponto de vista da pragmática do discurso, daria a ele uma maior autoridade, já que ele estaria assim falando não em nome de uma corrente específica, mas de toda a filosofia. Para manter esse seu "irenismo", como o define Lauwers (2015, p. 219), Máximo evita enfatizar as diferenças doutrinais entre pensadores e escolas. Acredito que devemos entender Máximo a partir de sua noção da unidade da filosofia, mas não podemos deixar de estudá-lo como um fenômeno particular dentro do medioplatonismo, já que a maior parte de suas ideias aponta para essa direção.

No discurso XXVI, 1, Máximo apresenta uma definição da filosofia: o conhecimento das coisas divinas e humanas, fonte da virtude e de pensamentos belos e da harmonia da vida e de hábitos corretos. Existe uma notável semelhança entre a primeira parte de sua definição e a definição de sabedoria por Alcínoo; a única diferença é que, enquanto para Alcínoo a filosofia é uma órexis em direção a esse ideal de conhecimento, para Máximo, ela é esse próprio ideal. Máximo também não fala em lúsis e periagogé, mas, tal como em Alcínoo, após enfatizar o aspecto epistemológico, afirma que ela é a fonte não apenas de pensamentos belos, mas também de atividades que se encontrariam 
no âmbito da práxis: a virtude, a harmonia da vida, os hábitos corretos. Em outras palavras, tal como em Alcínoo, a filosofia para Máximo seria um modo de vida baseado no conhecimento do todo.

É tendo isso em mente que podemos nos voltar para a apresentação de sua atividade filosófica que ele faz no Discurso I, interpretado por alguns estudiosos como uma introdução ao restante da obra. ${ }^{15}$ Como é comum em outros de seus discursos, Máximo começa construindo uma imagem, a partir da qual tirará consequências filosóficas: quando um autor, em uma peça de teatro, representa diferentes personagens, apresentandose de maneiras diferentes (em um momento como Agamêmnon, em outro como Aquiles, etc.), ninguém pensa ser isso algo incomum. Mas a vida, afirma ele, é como um drama que, por ser composto pelo próprio deus, apresenta uma história mais verdadeira. Assim, o que haveria de censurável se o filósofo, tal como o protagonista do coro, respeitando a dignidade dos versos, adapta o seu discurso de acordo com os episódios que formam a trama?

Máximo desenvolve o tópos da analogia do teatro com a vida humana de uma maneira inusitada: se, como os atores em um drama, somos personagens da trama de nossa própria vida, não seria adequado que modulássemos a nossa voz de acordo com os diversos episódios? Se Máximo fala aqui do filósofo, é que a filosofia não é entendida por ele apenas como um conhecimento desinteressado, mas como um guia para a vida em suas diversas situações. Existe, no entanto, uma nuance aqui: Máximo não fala em adaptar o comportamento, mas o lógos. Com isso, ele deixa de pensar apenas em theoría e práxis, mas leva em conta, tal como um orador hábil, também o lógos. Com isso, ele prepara o terreno para que seu ouvinte perceba a necessidade da retórica para a filosofia.

Ele então apresenta uma outra imagem que complementa a anterior: um músico é inútil se, sabendo tocar no modo dórico, fica em silêncio quando precisa tocar no modo jônico ou eólico. Do mesmo modo, o filósofo $(\mathrm{I}, 2)$ :

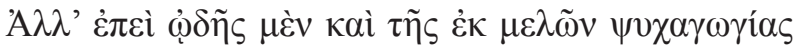

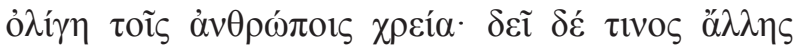

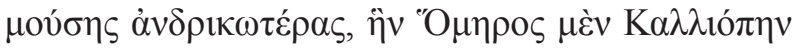

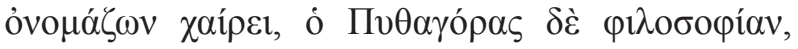

${ }^{15}$ Cf., por exemplo, Daroca; Cruces (2006, p. 93). 


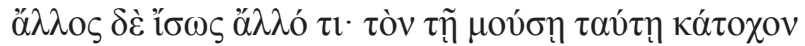

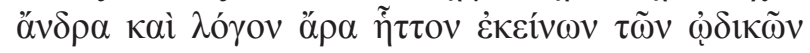

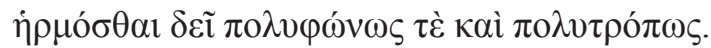

Mas, já que aos homens é pequena a necessidade de canções e da condução da alma por meio de melodias, é necessária uma outra musa, mais vigorosa, a qual Homero se alegrou em chamar de Calíope, Pitágoras de Filosofia e outros, talvez, de outro modo. E o homem inspirado por essa musa deve harmonizar o discurso em muitos tons e de muitos modos, não menos que aqueles que cuidam das canções. ${ }^{16}$

O músico deve ser versátil, mas sua habilidade com as canções e sua capacidade de realizar a psicagogia através das melodias é menos necessária que a habilidade do filósofo. É preciso, então, invocar uma outra musa, que Máximo, antecipando a sua tese de um Homero filósofo, afirmará que era conhecida por ele como Calíope, enquanto era chamada de Filosofia por Pitágoras. A analogia com a música continua: o homem tomado por essa musa deve ser ainda mais polifônico e polivalente que o músico. Sua atividade filosófica também deve ser realizada em muitos tons e de muitos modos. Se houvesse um padrão somente nos assuntos humanos, ele continua, não seriam necessárias harmonias versáteis. Contudo, a regra que a deliberação divina impôs aos assuntos humanos é a mudança.

Mas o que seria concretamente essa polifonia? Máximo afirma que a filosofia deve se adaptar constantemente ao momento e, tal como um médico habilidoso que regula a falta e a saciedade de um corpo instável, deve harmonizar o seu lógos de modo a se ajustar ao que nos acontece, oferecendo consolo nos momentos tristes e celebrando as ocasiões luminosas:

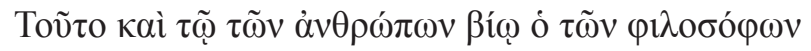

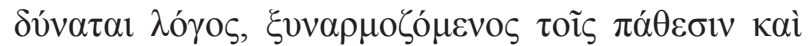

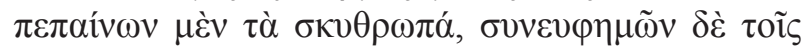

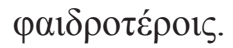

${ }^{16}$ Máximo de Tiro, Discursos I, 2. 
E é isto que o discurso dos filósofos pode fazer com a vida dos homens, harmonizar-se às paixões, tanto consolando nos momentos tristes quanto celebrando nos luminosos. ${ }^{17}$

A capacidade polifônica do filósofo é a habilidade de modular o seu lógos de acordo com a situação, tal como faz um bom orador. Mas o texto deve ser complementado por uma outra passagem (I, 10), na qual Máximo defende não a versatilidade do discurso filosófico, mas a unidade da filosofia: o filósofo deve ser julgado unicamente por sua inteligência, seu lógos e sua disposição da alma. Todo o resto, sua aparência, idade, status social, são elementos dispostos pela fortuna, tal como os trajes dos atores nas Dionísias. A beleza da poesia é a mesma, fale o príncipe ou o escravo, Agamêmnon ou Télefo, e o mesmo se dá com a filosofia. Os diferentes filósofos são como personagens enviados para o palco com trajes diversos, Pitágoras em púrpura, Sócrates em seu manto puído, Xenofonte com seu escudo etc. Esses são os elementos acidentais, tais como o modo como se apresentam: Pitágoras aturdindo o público, Sócrates o confundindo com questionamentos, Xenofonte o persuadindo, e Diógenes reprovando.

Daroca e Cruces (2006, p. 95) afirmam existir uma diferença importante entre a comparação com o ator que inicia o texto e a defesa da unidade da filosofia no final: na comparação com o ator, é a voz de um mesmo ator que é modulada de acordo com a variedade dos personagens, mas, em I, 10, são os diversos filósofos que se remetem a uma mesma sabedoria. Penso, no entanto, que as imagens são complementares: um filósofo deve saber modular sua voz de acordo com a circunstância porque é assim que a própria filosofia faz, se manifestando por meio das diferentes aparências dos diversos filósofos, ainda que seja uma só. Não é apenas o filósofo, mas a própria filosofia que, para ser mestra da vida em toda sua plenitude, deve ser polifônica.

Mas Máximo vai além: se a filosofia comporta polifonia e se manifesta das maneiras mais variadas, tudo o que há de valor na cultura grega pode, a princípio, ser entendido como uma expressão sua. Segundo ele afirma em XXVI, 2, para guiar as almas que encontrava de maneira suave, a filosofia se vestiu com o disfarce do mito, do rito, da música

\footnotetext{
${ }^{17}$ Máximo de Tiro, Discursos I, 2.
} 
e da profecia. É tendo isso em vista que ele pode, no Discurso XXVI, construir a sua imagem de um Homero filósofo.

Mas, já no Discurso IV, ele fala das relações entre o poeta e o filósofo. No início do texto (IV, 1), lembrando da antiga querela entre a poesia e a filosofia, Máximo nega que exista, de fato, oposição entre elas. São dois nomes, ele afirma, para uma mesma coisa. A poesia é uma forma mais venerável de filosofia, composta em metro e de expressão mitológica, enquanto a filosofia, mais recente, é menos formal na composição, mas mais lúcida na expressão. E ele continua: a medicina teve que se adaptar à mudança na constituição física de seus pacientes, causada por mudanças na dieta e no estilo de vida. Se a medicina antiga era mais simples, era porque os corpos eram menos degenerados e sofisticados e, assim, mais fáceis de serem curados (IV, 2). Pois o mesmo ocorreu com a filosofia: também a alma dos antigos era mais simples, exigindo um discurso mais delicado e artístico, que a guiasse através dos mitos, tal como a das crianças, que as criadas ensinam por meio de histórias tradicionais. Mas, com o passar do tempo, a alma dos homens se tornou mais desconfiada e menos capaz de suportar um estilo indireto de ensino. Por isso, despojaram a filosofia de seus trajes poéticos. Mas, se mudou a apresentação, o essencial permaneceu o mesmo: Homero e Hesíodo não são menos sábios que Aristóteles, Crisipo e Clitômaco, mas talvez até mais do que eles (IV, 3 ).

Máximo afirma que a linguagem poética era mais adequada para a expressão da filosofia nos tempos antigos, mas, na sequência do texto $(\mathrm{IV}, 6)$, louva os seus méritos, dando a entender que, ao menos em certos contextos, ela ainda pode ser adequada para os homens de seu tempo. Se a filosofia é desagradável para a maior parte das pessoas, ele afirma, a arte poética consegue torná-la mais palatável. Tal como os médicos que misturam o remédio amargo a uma comida agradável, o metro e a forma poética escondem o que há de difícil no ensinamento.

Mas, ainda que seja adequada em certos contextos, isso não significa que a poesia seja necessariamente superior à prosa filosófica. Em IV, 7, Máximo afirma que a poesia é como o escudo dourado de Aquiles, enquanto a prosa se assemelha ao escudo de Ájax, feita com material inferior: o ouro pode ser superior, mas não é ao escudo, mas à virtude do herói que o usa que devemos dirigir nossa atenção. O que importa é a verdade, seja ela expressa em mitos e por meio da arte poética, seja em prosa. Se não há verdade, roubamos o poema de sua 
poesia e transformamos a doutrina em mito, tal como fez Epicuro, ${ }^{18}$ cuja doutrina de que os deuses não se importam com o nosso mundo é ainda mais inacreditável do que o que contam os poetas (IV, 9).

Homero é apresentado por Máximo como um filósofo no Discurso XXVI. Exteriormente, ele afirma (XXVI, 4), seu lógos é formado por mitos. Contudo, ao falar de Troia e de Odisseu, ele apresenta uma teologia lúcida, uma síntese das formas políticas, bem como o relato dos vícios, virtudes, desastres e sucessos da vida humana (XXVI, 4). A exegese alegórica de passagens dos poemas homéricos foi amplamente desenvolvida no neoplatonismo. ${ }^{19}$ Mas Máximo não está interessado em atribuir doutrinas platônicas a Homero ou em afirmar que aquilo que Platão manifestou em sua plenitude, Homero aludiu de modo enigmático. Pelo contrário, para afirmar a unidade da filosofia, que se manifesta de várias formas, em IV, 3, ele defende a noção de um Platão homérico, um filósofo que, ele ousa dizer, é mais semelhante a Homero que a Sócrates, por mais que tente escapar de um e se aproximar do outro. E isso não apenas no estilo e na linguagem, mas no pensamento.

Outra consequência da polifonia da filosofia é a sua abertura para a arte retórica. Segundo interpreto o Discurso I, todo ele é construído tendo em mente um objetivo: defender a proposta de Máximo de ser um filósofo que também é um orador. Como vimos em I, 2, dada a variedade da vida, o filósofo deve ser capaz de modular o seu discurso segundo a situação, tal como um orador habilidoso. Mas Máximo vai além: o filósofo não deve ser apenas capaz de adaptar o seu lógos ao páthos de cada situação, mas também de evocar o páthos que sirva de impulso à vida filosófica a partir de seu lógos. Reconhecendo a importância das paixões para o filósofo, ele escreve:

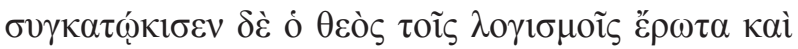

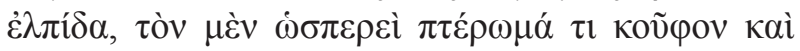

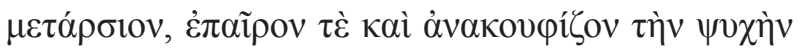

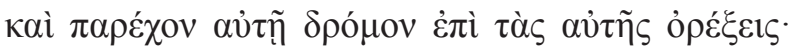

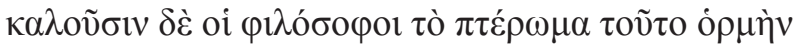

\footnotetext{
${ }^{18}$ A doutrina da harmonia entre os filósofos de Máximo tem uma exceção, que confirma a regra, no entanto, por se tornar o paradigma da antifilosofia: o epicurismo, em especial por suas ideias a respeito dos deuses e do prazer como o télos da vida humana. Cf., por exemplo, IV, 8-9.

${ }^{19} \mathrm{Cf}$., por exemplo, Pepin (1981).
} 


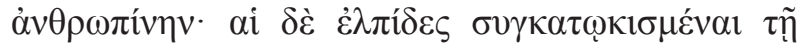

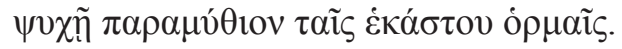

O deus juntou aos raciocínios o amor e a esperança. Um é como uma asa ligeira e suspensa, que levanta e eleva a alma e lhe permite correr em direção aos seus desejos. Os filósofos chamam essa asa de impulso humano. E as esperanças foram ligadas à alma como exortação aos impulsos de cada um. ${ }^{20}$

Se o raciocínio é aquilo que caracteriza o modo de vida filosófico, ele, no entanto, não é o único elemento presente à alma humana, para a qual também existem as paixões. Máximo fala aqui em esperança e, seguindo uma tradição platônica que remonta ao Banquete, em éross. A potência racional apenas não basta: a alma deve ser impulsionada pelo páthos. O amor é, assim, um impulso (hormé), como uma asa que torna a alma leve e a eleva para a corrida que segue na direção do desejo. A palavra aqui usada é, tal como em Alcínoo, órexis que, sendo empregada na definição corrente de filosofia no medioplatonismo, acredito que apareça aqui como um eco dessa definição: a oréxis da alma é, sobretudo, a sabedoria. A esperança, por sua vez, é um paramúthion, um encorajamento, uma exortação, por insistir que o objetivo é passível de ser alcançado. Mas, se o páthos também é necessário à filosofia e se é a arte retórica aquela que dota o lógos da capacidade de suscitá-lo e ainda, se é o orador aquele que é mais capaz de realizar tudo isso, não seria a oratória uma forma legítima de filosofia? Máximo em nenhum momento tira essa conclusão, mas deixa dispostas todas as suas premissas.

Contudo, ainda que as paixões sejam importantes, o fundamental é o raciocínio. O filósofo deve ser um bom orador, mas o orador deve ser um filósofo. Do contrário, torna-se um sofista:

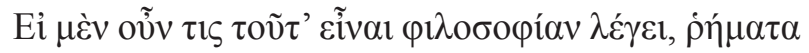

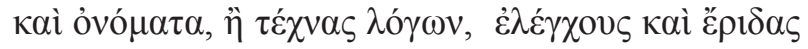

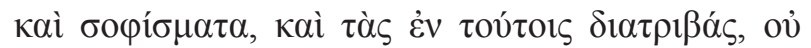

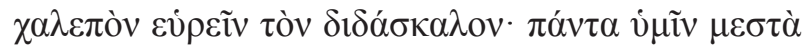

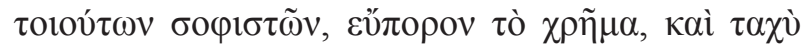

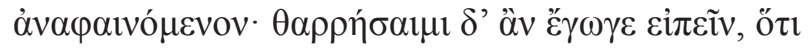

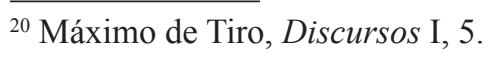




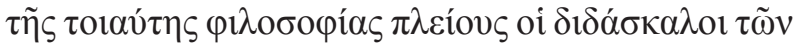
$\mu \alpha \theta \eta \tau \tilde{\omega} v$.

Se então alguém diz que a filosofia consiste em verbos, nomes ou na arte das palavras ou ainda em refutações, disputas e sofismas, passando o tempo com essas coisas, não encontrará com dificuldade um mestre. Todos os lugares estão cheios destes sofistas para vocês e o assunto é fácil e rapidamente se manifesta. Ousaria mesmo dizer que, desta filosofia, mais numerosos são os mestres que os discípulos. ${ }^{21}$

Se adotamos a hipótese de Lauwers, de que existem dois sistemas a partir dos quais se empregam os termos sophistés e philósophos na Antiguidade, vemos que Máximo adota aquele que contrapõe à sofística a filosofia, ainda que, para nós, ele seja um autor mais próximo da Segunda Sofística que da Filosofia. O mundo está cheio de sofistas, ele afirma, que gastam tempo com palavras, sofismas, refutações e disputas. Máximo parece aqui estar se referindo àqueles que se dedicam à retórica, mas as atividades que ele condena são aqueles estudos por parte dos que se focam na lógica e na dialética. $E$, de fato, na sequência do texto (ainda em I, 8), ele afirma que o que é necessário é um mestre capaz de elevar a alma de seus estudantes, guiar suas ambições e de temperar seus desejos com o auxílio de prazeres e dores, tal como fazem os treinadores de cavalos. O ensino que guia a alma humana deve ser composto de modo a seduzir e comover. Em outras palavras, deve ser realizado por um orador capacitado.

\section{Conclusão}

A filosofia se diz de muitos modos. Se para alguns sua marca é o uso de argumentos lógicos, para outros o que a define é ser um modo de vida de acordo com a sabedoria. Vemos, a partir da análise dos textos de Alcínoo e Máximo de Tiro, que, mesmo no ambiente do medioplatonismo, concepções diversas circulavam, ainda que com pontos de interseção. Tanto para Máximo quanto para Alcínoo, a filosofia diz respeito ao conhecimento das coisas divinas e humanas. Para ambos,

\footnotetext{
${ }^{21}$ Máximo de Tiro, Discursos I, 8.
} 
esse conhecimento também implica na adoção de um modo de vida que o leve em conta: a práxis segue a theoría. Mas que vida é essa? Tanto um quanto o outro falam em virtude e conduta. Contudo, enquanto Alcínoo propõe como meta a semelhança com o divino alcançada em uma vida de investigação e meditação, na qual nossa atenção se desvia dos assuntos humanos para o inteligível, Máximo, a partir de sua noção da polifonia da filosofia, dá a entender que a vida filosófica, ainda que reporte a uma mesma sabedoria e a um mesmo estado de alma, pode se manifestar de diferentes formas. Com isso, também a eloquência e a arte poética tornam-se úteis para o filósofo, o que outros autores do período, como Díon Crisóstomo, mas também Plutarco e Apuleio, no contexto do medioplatonismo, parecem igualmente pensar.

\section{Referências}

BRANDÃO, B. A tradição do discurso apofático na Filosofia Grega. Hypnos, São Paulo, n. 18, p. 90-97, 2007.

COOPER, J. Pursuits of wisdom: six ways of life in ancient philosophy, from Socrates to Plotinus. Princeton: Princeton University Press, 2012.

DAROCA, J.; CRUCES, J. Maxime de Tyr et la voix du philosophe. Philosophie Antique: problèmes, usages, renaissances, Lille, n. 6 (Lire et interpréter Platon), p. 81-105, 2006.

ALCÍNOO. The Handbook of Platonism. Trad., introdução e comentário de John Dillon. Oxford: Oxford University Press, 2002.

HADOT, P. O Que é filosofia antiga? Trad. Dion Davi Macedo. São Paulo: Loyola, 1999.

KONIARIS, G. On Maximus of Tyre: zemetata(II). Classical Antiquity, Berkeley, v. 2, n. 2, p. 212-250, 1983.

LAUWERS, J. Philosophy, rhetoric and sophistry in the High Roman Empire: Maximus of Tyre and twelve other intellectuals. Leiden: Brill, 2015.

LAUWERS, J. Systems os sophistry and philosophy: the case of second sophistic. Harvard Studies in Classical Philology, Cambridge, MA, v. 107, p. 321-363, 2013. 
LAUWERS, J. The rhetoric of pedagogical narcissism: philosophy, philotimia and self-display in Maximus of Tyre's first oration. The Classical Quarterly, Cambridge, v. 59, n. 2, p. 593-607, 2009.

MÁXIMO DE TIRO. The Philosophical Orations. Trad. e introdução de Michael Trapp. Oxford: Oxford University Press, 1997.

PEPIN, J. The platonic and the Christian Ulysses. In: O'MEARA, D. Neoplatonism and christian thought. Albany: Sunny Press, 1981.

SEDLEY, D. The "Theoretikos bios" in Alcinous. In: BENATOUIL, T.; BONAZZI, M. Contemplative life after Plato and Aristotle. Leiden: Brill, 2012. p. 163-182.

SELLARS, H. The Art of Living: the stoics and the nature and function of philosophy. Londres: Bristol Classical Press, 2009.

STANTON, G. Sophists and philosophers, some problems of demarcation. The American Journal of Philology, Baltimore, v. 94, n. 4, p. 350-364, 1973.

WARBURTON, N. Elementos básicos de filosofia. Trad. Desidério Murcho. Lisboa: Gradiva, 1998.

WHITTAKER, H. Parisinus Graecus 192 and the writings of Albinus. Phoenix, Ontario, v. 28, p. 320-354, 1974. 